\title{
Manajemen Education And Training In Improving Employee Performance On Sonder District Office
}

\author{
Meike D. Mamentu \\ Faculty of Economics, University of Manado-Indonesia
}

\begin{abstract}
Management of human resources affect the quality of the workers. Education and training is an important element to improve the performance of employees at the district office Sonder Minahasa. The method can be used to prove the performance of employees, using correlational and quantitative approaches. The data analysis technique used is simple linear regression, the product moment correlation coefficient determinant and significant test $(t)$. The sampling technique using purposive sampling techniques to obtain 29 respondents. The results showed that there is an influence on the implementation of education and training to improve the quality and performance of employees in the district office Remboken Minahasa district with a simple linear regression analysis showed that $Y^{\prime}=33.08+0.39 X$ which means there is a causal relationship between education and the implementation of training with employee performance. The results of correlation analysis, $r$ $=0.54$ obtained show the existence of the relationship between the implementation of education and training with employee performance. In deciding the degree (correlation coefficient) indicates $r 2=0.29$ or $29 \%$, stated the contribution of education and training on employee performance by $29 \%$ while $71 \%$ are still other things that are caused by other factors diuar education and training. With the use of the test was obtained t count $>t$ table is not a table or $3.34>2.052$. So this hypothesis Ho is rejected and Ha accepted keberartianya, in which education and training can improve employee performance.
\end{abstract}

Keywords: Education and Training, Employee Performance

\section{Introduction}

Management education and training of human resources is a very decisive implementation of organizational goals offices. Where employee performance plays an important role for the survival and development of the organization, in line with the progress of knowledge and the influence of globalization, if no employee is necessarily supported by the ability of the organization can not progress and develop. Staffing agency area in particular districts Sonder Minahasa Regency is a government agency that has the task of implementing the government's affairs into the regional authority in the field of personnel. Under Law No. 8 of 1974 on employment subjects as amended in Law . 43 Year 1999 Article 1, paragraph 1 : Civil Servants ( PNS ) is every Indonesian citizen who has been determined eligible, appointed by the competent authority , entrusted with the task in a country office, or other State and assigned the duty paid by the laws and applicable regulations . Implementation of task execution and control activities meliputu field service personnel in accordance with the legislation in force and the policy of regional heads. For the employees of the Regional Employment Board is required to work in a professional manner, realizing a quality service, knowledgeable, disciplined and have a high commitment and able to face the challenges of the times. In fact there is a problem through observation indicates the level of performance which is not optimal in the district office Sonder Minahasa. For it is based on local regulations it is necessary to providing education and training appropriate to the duties of the personnel function. For example, in-service training, in which the government sets regulations utilization of state apparatus and bureaucracy reform explains the role that should be done both at a management level employee with delivery units in the functions assigned duties in the office. Position is part of the human resource management process that is used for weighting a position to generate value positions (job value) and class positions (job class). Value and a class of positions used to determine the amount of work and wage rate given by the workload and responsibilities of the position. In Article 7 Paragraph ( 1 ) of Law No. 43 Year 1999 on Amendment to Law No. 8 of 1974 on the Principles of Civil Service mandated that every servant entitled to a fair and decent salary in accordance with the work load and responsibilities. The work needs to get a judgment that shows the performance of employees working in the office. Positions in the civil service carried out to determine the value of office, the next class will be used in determining the position and can be used among others in implementing employment programs, such as : preparation of formation, career systems , performance, and benefits administration system penggajian.Tujuan this policy so that every ministries/agencies and provincial/district/city and sub-standard pattern and ranking positions in the preparation of civil servants in their respective communities and can be run in accordance tigas ratings assigned positions. Government agencies are next in rank positions and functions guidelines intended duties on all employees in all government agencies jengjang in the region, namely the ministries/agencies and provincial/district/city and district. Position 
is a position that shows tasks, responsibilities, powers, and privileges of civil servants in the state organizational unit. Employee job performance can be measured through job evaluation guidelines. Job evaluation is a process for systematically assessing a position using the criteria referred to as a factor to the information office of factors to determine the value of the post office and classroom positions that show the performance of work achieved. To assess the feasibility work can be formulated in the map office. Map Position is office arrangement depicted vertically or horizontally according to the structure of authority, duties, and responsibilities of positions and job requirements. Map positions illustrate all existing positions and position within the work unit. To carry out the work to be performed to the profession of the employee. Professional job is a job that requires knowledge in a field of knowledge acquired through undergraduate education / equivalent or higher used to make new discoveries, new interpretations, developing the data, materials, and new methods. Professional positions can be assigned in the functions of government tasks and functions of the functional tasks as Doctors, Nurses, Clinical Psychologists, Pharmacists, Teachers, and others. There is an administrative job that requires analytical skills, judgment, and responsibility of employees in the application of principles and concepts of knowledge that can be applied to the field of administrative or management job, and does not require a field of science or education specialization acquired through undergraduate education / equivalent or higher acquired through education and training for the development of applied sciences in developing their profession according to the task and work as a patent examiner functional positions, positions the brand inspector functional, functional position of health administrators, office personnel expert level functional analysts, and others. This is the so-called technical work. The technical work is supporting the work of professional work and administrative work, such as technical functional positions Dentistry , functional positions analyst skilled staffing levels, functional position of assistant pharmacists, and others. And there is support work called clerical work. Clerical job is a job of work supporting administrative/office as typist functional position, functional position courier, agendaris functional positions, and others. There is also a structural position that perluh trained for the achievement of duties. Adherence to the task of the employee appraisal district is given the appropriate assessment guidelines indicate kenerja works. The Deputy field for human resources ministry officials as the highest pengelolah manpower and personnel and is responsible in determining the performance of employees under the laws the State Personnel Board, and the agency concerned, jointly validate the value of the post office and classes for every level existing positions within government agencies, both structural position and functional position specific/general functional positions at the district level cities and districts as an extension of the subdistrict level staffing agency responsible for reporting the performance of employees who are employed in the form of report as a result of the government's appropriate supervisor with their duties and functions in accordance accountability in carrying out their duties at the district level .

Deputy for the field of human resources ministry, deputy field performance and Legislation State Personnel Board, for the government agencies that provide detailed instructions ditentukkan task function together in validating the value of the post office and classes for every level of the position that is in environmental agencies pemrintah start at the top level of government and at the district level administration. For the subdistrict level assessment by the districts that validate adherence to duty, both structural and functional positions positions and certain positions/general functional position. The results of a validation study, map position, results of job evaluation (Value Position and Job Class) and factor information office as a result of job evaluation of structural and functional position specific/general functional positions that are valid in the subdistrict government agencies performing work achieved. Results of class positions made in the minutes of the work is assessed in class positions. The results were assessed in the environmental assessment agencies will be used in the working districts accountable for the performance of work of employees working at the sub-district levels of government accountable. Assessment was made of documents comprising the form of an official report, a summary of the value of positions and class positions, map position, results of job evaluation and functional position of certain structural/functional position and the common factor structural position information, position specific functional/functional position of general structural initialed by the officer who commissioned and signed by the head of the district. In the implementation of the strategy map pennyusuna job positions need to be trained in the task. Implementation of education and training is concerned, the inventory every good structural or functional positions (general and specific) contained in each unit of work (for all echelons), the composition of the entire post of vertically and horizontally based on the position of each position within the work unit (for all echelons) and all employees who are working in all the existing organizational structure at district level regarding : (1) stacking number of employees for each position are included in the unit, (2) map that is composed of office will explain the arrangement and relationship of each office within the work unit (for all echelons). Furthermore, the education and training of employees pelaksnanaan knowledge of preparation of the information supplied factors functional and structural positions. Arrange the steps of information and preparation of structural position factor information is as follows : ( 1 ) write the function name is taken from the name of the post office on the analysis, (2) write roles taken positions on the analysis of the role of the post office, (3) write a description duties and responsibilities are taken from the job description and 
responsibilities of the job analysis results. (4) write the work positions are taken from the work of the job analysis results. (5) board -level factors related to, the scope and impact of the program based on the details of office tasks , organizational settings based on the location of the post office on the analysis , and the supervisory authority managerial positions of authority based on the results of job analysis, personal relationships based on the results of the analysis of the post office relationships, difficulties in directing the work based on the level of difficulty and complexity of the work in the main base unit, other conditions based on the level of difficulty and complexity in implementing the obligations, powers, and responsibilities supervision, and write the specific job requirements, if there are specific requirements for the job and comes with the job date information compiled.

Education and training factor information based on the analysis fungsiona office positions such as preparation steps factor functional position information is as follows: write the function name is taken from the name of the post office on the analysis, wrote the role of positions taken from the results of the analysis of the role of the post office. written description of duties and responsibilities that are taken from the job description and responsibilities of the job analysis results. Write the work positions taken from the Work on the results of job analysis. board -level factors related to: the knowledge required by the job description of office positions, supervisory oversight by supervisory authorities or officials at the structural level higher, based on the type of regulatory guidelines and procedures needed to carry out the job description and necessary considerations, complexity based difficulties in identifying and carrying out the work, the scope and impact of the work based on the scope and impact of the work or services inside and outside the organization, personal relationships and goals based relationships and how to communicate the intent of the communication based on the results of job analysis, physical requirements based on requirements and minimal physical demands in the performance of duties based on job analysis, work environment based on the results of the working conditions of the job analysis, writing functional job requirements if there are specific requirements for the job and complete the job date information is compiled.

Education and training penysunan job evaluation results . Training positions constitute the evaluation of structural and functional information based on factors such as the structural and functional positions preparation steps on the evaluation of structural and functional positions are as follows : compare each factor level position information will be assessed by the level of factor level positions on the evaluation factors and structural position existing functional, information for each factor level positions, select the level of factor as it is and to get the value of each level factors: total the value of each level of a factor to get the total value of office factor, compare the total value factor table positions with the limit values and class positions, namely: class structural and functional position.

Education and training of organizational settings. This factor considers the organizational situation some level supervisory positions. If the office is responsible for two positions, then choose a level factors associated with positions that have responsibility for performance appraisal. This position is accountable to a position that is at one or more levels below the highest structural position. For example, the lowest position in the chain of command, or a position equivalent or higher level in the chain of direct supervision. This position is accountable to a position that is one level below the highest structural position or a similar position in the direct supervisory chain. This position is the highest structural position.

Education and training supervisory and managerial authority. These factors include supervisory and managerial authority are executed repeatedly. To be assessed in this factor, a position must meet the provisions of the authority and responsibilities described for factor levels. The rate factor is used for a specific program guidance, line functions, staff functions, and operations and support. If authorized duplication or indistinguishable among several levels of the organization, then a level factors can be used for office at some level of organization. Positions at this level meets the following conditions: plan and schedule work oriented output every 3 months and every year, or direct the same task duration, adjust the employee class or working procedures within the organizational unit to make resource allocations at levels that were higher, considering the purchase of new equipment, improve work methods and procedures digunaka, overseeing the development of the data, estimates, statistics, advice, and other useful information to higher authorities in determining the priority goals and objectives, deciding the methodology used to achieve the goals and objectives, to determine other management strategies. If the work contracted out, provide a variety of technical input and supervision equivalent to all or nearly all of which include: analyzing the benefits and costs of implementation of the work if it is done within the organization or contracted out to other parties, give advice whether the work should be contracted out to other parties and provide requirements and technical description of the work to be carried out . Then planning and scheduling, time limits, and acceptable standards of work, coordinate and integrate contractor work schedule with the work of subordinates or others, track the progress and quality of work, arrange subordinates perform the required inspection, decide to accept, reject, or corrected work product or service affects payments to contractors, carrying out at least three of the first four, and six or more of the ten powers and responsibilities of the following: planning work performed by subordinates, set and adjust shortterm priorities, and prepare schedule for completion of the work, giving the work to subordinates based on 
priorities, level of difficulty and requirements of assignments, and the ability of employees, evaluating the performance of subordinates, give advice or guidance to personnel issues and administrative jobs, interviewing prospective employees in a work unit, provide a recommendation for appointment, promotion or transfer assignment to another position, listen to and resolve complaints from employees, minor disciplinary action, such as warnings and reprimands, giving advice on other actions in more serious cases, identifying training and development needs of employees by means of providing or arranging for needed development and training, find ways development of output or improve the quality of jobs that are directed and develop performance standards . In order to achieve this level, then the office must meet the following requirements: (1) run the managerial authority to establish a plan and schedule the annual and multi -year work in their own environment or the work contracted out (2) ensure the implementation ( by lower organizational units or other ) goals and objectives of the program segments or supervised functions ( 3 ) determine the goals and objectives that need to be emphasized, determining the best approach or solution to resolve budget problems, and plan for the long-term staffing needs, including whether to contract out the work to another party. This position is closely linked with the highest structural officer (or officers staffing agencies) to develop the goals and objectives of staff development, program, or program segment. For example, the position directs the development of the data, the development of skills and insights or obtain public opinion, the preparation of papers or proposals of legislation and implementation of similar activities that support the development of goals and objectives related to program management and development or formulation at a higher level. Furthermore, carrying out all or almost all of the powers and responsibilities of supervision at the level of these factors is at least that is, direct, coordinate or supervise the work of supervisory officials, work team leader, group coordinator, chairman of the committee, or equivalent employees and/or to supervise, execute responsibilities in handling large enough officials in organizational units or other organizations, or provide advice or judgment to an authority higher class, ensuring fairness (among units, groups, teams, projects, etc.) standards of performance and value determination techniques developed by subordinates, or to ensure fairness of assessment on the ability of the contractor or subordinate work completed by the contractor, directing the program or program segment that uses a great resource (eg a multi billion dollars in annual budget), make decisions on work problems presented by subordinate supervisors, team leaders, or equivalent employees, or contractors, officials evaluate subordinate supervisors or team leaders, and serves as an official observer to the functional performance evaluations assessed by officers subordinate supervisors, conduct or approve the selection functional employees in its environment, recommend the selection officers subordinate supervisor, team leader, group leader, or project director positions that coordinate the work of others, and similar positions, listen and resolve grievances or complaints employee groups, reviewing and approving disciplinary action (ie warning ) employees functional subordinates, making decisions about the need for expensive training or controversial and submission of employee training, work carried out to determine whether the contractor has met the required standard of sufficiency for payment authorization, approved a budget increase in class positions, overtime, and employee business travel, recommends award for employees and changes in functional class positions, find and implement ways to eliminate or reduce barriers to work, improving the development team, or improve work methods. Positions at the level of these factors must meet the added factor: overseeing all planning, direction, and execution of a program, several program segments (which are managed by some subordinate organizational units), or some equivalent staff functions, including development, assignment, and achievement goals and objectives of organizational units subordinate supervisory officials, approved the work plan long-term (multiyear), which was developed by the supervisor of officials subordinate organizational units and manage all the work to improve the achievement of goals and objectives, monitor changes in long-term plans, goals and objectives of the work are directed, managing the allocation of funds rate changes or other changes as a result of the development of policy changes or legislation pelican, managing organizational change directed, or major changes in the structure and content of programs or program segments directed, the budget allocated in the organization, and assign personnel actions and organizational design proposals recommended by subordinate supervisory officials.

Education and training of the duties and responsibilities of the job with the main office in uaraian following tasks: (1) formulate policies for the welfare of human resources (2) coordinate the preparation of policy formulation in the field of welfare of human resources (civil servants and state officials) include: salaries and benefits, housing savings, health insurance , education insurance sons/daughters of civil servants, pensions, retirement savings, honoraria, financial rights, honorarium, and other facilities to state officials and other officials , to coordinate the monitoring, analysis, and evaluation of the implementation of policies in the field of human welfare sumbwr apparatus, coordinate the preparation of the performance accountability of government agencies (LAKIP) in the field of welfare of human resources, promoting policies that had been Minister of State for structuring guideline-based employee competence in the field of welfare of human resources, provide information and solutions to the problems that were consulted by the management officer staffing at central and regional agencies in the field of welfare of human resources, directing and distributing tasks subordinate welfare 
of human resources, reporting on the activities in the field of welfare of human resources as a liability execution of tasks. Kemuadian responsible, ensuring compliance plans and programs for the future welfare of human resources with the strategic plan of personnel resources. Policy in the field of human resource welfare apparatus includes salaries and benefits, welfare, and incentives/other facilities. As well as the work of the strategic plan document stated the welfare officer of human resources/personnel and the formulation of draft regulations on the amount of human welfare apparatus/personnel proposed. The scope and danpak this program include direct job positions in the administrative complex, which includes the development of several important aspects in the development of policies / regulations in the field of welfare of human resources/pegawi . This position also affect the accomplishment of the mission or programs of government agencies and local districts in the continuous attention of the House or of the local mass media.

Education and training of organizational settings . This position is responsible for managing the field of human resources / personnel ditugaskann in positions to supervisory and managerial authority. This position is authorized to determine , among others: (1) annual work plans and schedules and multi -year work assignment in the districts untu welfare of personnel resources including contracted work. (2) ensure the implementation of the goals and objectives of the work, preparation of policy formulation in the areas of salaries and benefits, the welfare of human resources, and incentives / other facilities (3) determine the goals and objectives that need to be prioritized (3) determine the best approach or solution in planning long-term staffing needs and work contracted out (4) directs a program segment of welfare development of human resources that require sizeable resources (in accordance with the annual budget) (5) take a decision on the issues raised by the work of structural officials in the districts for kesejaktraan environment of human resources (6) evaluate and assess the performance of the head of salaries and allowances and head of welfare and job performance Kasubbid set salaries, allowances kasubbidang, and functional authorities and analyze the welfare apparatus (7) conduct or approve types of functional positions that exist in the districts for the welfare of the environment of human resources / personnel (8) listening and problem-solving employees in the working environment of the subdistrict ( 8 ) Review and approve employee discipline violations under it (9) determine the results of the work carried out by consultants as the basis for payment of honoraria of consultants (10) proposed the fee required in the implementation of activities and official travel of employees within the districts to the welfare of human resources / personnel sub-district (11) find and implement ways to reduce barriers to the achievement of the organization's output, an increase in the development of team work, or improvement of working procedures in the districts to the welfare of human resources/employee districts. Description of the tasks in the implementation can be dirinsci as follows: (1) evaluating the personnel to complete the form and ensure the suitability of its contents (2) conduct orientation for new staff. (3) enter data into the payroll system employees (4) assemble and maintain official personnel folder (5) follow the due date, such as the maturity period of employess (6) complete the employee requests in terms of changes in the data, such as health insurance coverage, etc. (7) resolve problems and differences that exist, such as adjusting the computer records in the job description and organization of data (8) perform tasks such as the calculation of severance pay , retirement annuity verify, resolve problems in payroll, and evaluate and make recommendations on specific personnel action (9) provide regular information on employment, such as how to fill out forms, employee job information, and tanggat time of registration. This can ensure compliance staffing data and matters relating to employee payroll . The work becomes work -to-date employee data, payroll data is accurate, and data on the number of new employee orientation. Thus the role of the workers are very clear through education and training so as to carry out the task dikecamatan employees who already participate in education and training can be provided with a clear duty material and can work to its full potential can be achieved menperlihat job performance. For that we need adnya management of human resources in implementing the education and training of personnel changes and districts in order to improve the quality of the workers. The changes are expected to be better able to work the machine as shown from the results of the work performance of employees. There are several factors that affect performance, namely the implementation of education and training are not optimally implemented so as to make optimal employee productivity, low work motivation in doing the work, then the lack of facilities and infrastructure required for the planning and proposing means working paper commissioned officers are not clear , making the lack of necessary facilities, uncomfortable working environment makes employees work can not be completed properly or can not be resolved properly in accordance with the expected sub-district head, it is necessary to equip the work through education and training

It is important to improve the performance of employees concerned in carrying out the work. Because the management of employees through education and training is not solely for the employee, but also a boon for the district office organization. Penidikan and training can improve employee 's ability to do the job. The use of the term education and training in an institution or organization, usually incorporated into training (education and training). As expressed by Notoatmodjo $(2009 ; 16)$ that education and training is an effort to develop human resources, particularly to develop intellectual abilities and personality in carrying out tasks/work them to the 
need for education and training of the employees duties districts to determine the function tasks assigned to them properly and can perform all tasks assigned.

Education and training in general related to preparing candidates used by an organization, while training has more to do with increased capabilities or skills of workers who have occupied a particular position or task. The new employee occupying a particular position may not necessarily have the appropriate capabilities, so it needs additional capabilities they need. Similarly, employees who have occupied the position, skills or his ability to be improved in order to achieve organizational goals. According Notoatmodjo (2009). The importance of education and training programs are as follows: (a) new employees occupying a particular position in an organization, not necessarily have the skills required in accordance with the requirements in the job (b) with the progress of science and technology, will clearly affect an organization/agency. Therefore, positions that are not required before, are now required. (c) promotion in an organization / institution is a must, if the organization would develop. Sometimes the ability of an employee to be promoted to certain positions is still not enough (d) at the time of this development organizations or agencies, both government and private feel compelled to provide education and training for employees in order acquired the effectiveness and efficiency of the work in accordance with the construction period. According Notoatmodjo (2009:23) education and training of employees in an organization or institution is usually grouped into two, namely training before running a task or job (pre - service training), and training after stints (in service training): (a) pre - service training that is before staff members or job duties, staff members must undergo education and training positions usually called pretraining (pre-service training). (b) In service training is training that is aimed at employees who are already working in different units or division of an organization or institution, so called in-service training or in-service taining . According Notoatmodjo (2003), education and training is a process that will result in a change in behavior training . Education and training process as follows : analysis of training needs. Set goals. Curriculum development. Preparation of training. Implementation of training. And Evaluation.

The benefits of education and training according to Wursanto (2001:60) is (a) training and education of employees improves stability, (b) improve the way employees work (c) Employees may develop rapidly, (d) the training and education of employees able to work more efficiently, (e) an employee is able to perform the task better, (e) employees are given the opportunity to develop themselves, (f) improving employee morale and productivity . And the objectives of education and training according to (Sedarmayanti, 2007:170 ), among others: (a) increase the spirit of devotion, insight, knowledge, expertise and skills (b) develop positive thinking patterns, rational and objective (c) create or develop better working methods and develop a career employee. In carrying out education and training according to the method used Notoatmodjo (2003:37), namely: (a) Method On The Job Site (on the job), this form of training new employees assignments under the guidance of supervisors who have experienced (senior), (b) method of Off the job Site (outside of work), education and training by using this method means the employees as participants in education and training activities to the outside while on the job. Education and training provides the knowledge needed employees who occupy positions that ditugaska. This factor measures the nature and extent of information or facts that should be known to employees who occupy positions that are assigned to carry out the work, among others: the steps, procedures, practices, rules, policies, theories, principles, and concepts, and the nature and level of expertise needed to apply that knowledge. Knowledge about the task or operation simple, routine, or recurring, that specifically follow the instructions step by step, and little or no need of training or prior experience. In the education and training of personnel districts equipped with the skills to run simple appliances or equipment that operates on a regular basis, which is little or no need of training or prior experience. Then where employees can be trained also equipped with the knowledge and skills equivalent. Employees districts can also be equipped with knowledge of procedures, rules, or the basic or general operations, which typically require little training or previous experience. Thus employees have the basic skills to operate equipment that requires little training and experience, such as a keyboard equipment adn equipment or obtain knowledge of Administrative laianya equivalent ketrampilanya. Equivalent knowledge and skills is the knowledge of a number of rules, procedures, and operations, which requires training and experience to carry out the work of clerks and resolve problems that arise or skill that requires training and experience, to operate and adjust equipment in a variety of purposes, such as carrying out a number of tests or operating standards so employees need to get an education and equal pelatuhan. Then the sub-district officials also need to be equipped with the knowledge of a number of rules, procedures, or operations, which require extensive training and experience to carry out various jobs that meet the standards and interconnected, and solve various kinds of problems. Practical knowledge of standard procedures in the field of engineering, which require extensive training or experience, also need to be owned by the employee districts namely: execute jobs requiring equipment that requires consideration and certain characteristics, interpret test results based on experience and previous observations (without reading directly instruments or other measuring device), and or make the essence of information from various sources and consider the characteristics and quality of the resources to be applied where they are equipped with the knowledge and skills equivalent. The employee can also be equipped with a sub-district knowledge (gained 
through an undergraduate education program or equivalent in experience, training, or self study) on the basis of principles, concepts, and methodologies of professional work or administrative work, and skill in the application of this knowledge to perform the tasks, operations, or procedures as a basis for increased educational career. Additional education is required for the practical knowledge of the methods of technical $t$ carry out work such as projects requiring complex and specialized engineering and education/skills equivalent knowledge.

Employee performance, a term derived from the performance or Actual Job Performance Performance (actual performance or achievements that achieved by someon). performance (performance) is the result of the quality and quantity of work achieved by an employee in carrying out their duties in accordance with the responsibilities assigned to him (Mangkunagara, 2005:67). Notoatmodjo (2009:21) says that the employee's performance is influenced by many factors that shortened to ACHIEVE, which means: Ability (abilities that can be developed and can intervene through education and training), Capacity (ability to pre-defined/limited), Help (assistance to realization of performance, incentive (material and non-material incentives), environment (working environment of employees), Validity (guidance/instructions, and job descriptions), and Evaluation (feedback work). Measuring Performance, by Bernadin \& Russell, 2001 Riani , 2010; 99) are as follows: (a) the quantitiy of work, amount of work done within a specified period (b) quality of work, quality of work achieved by the terms of suitability and readiness (c) job knowledge, breadth of knowledge and skills on the job (c) Creativeness, originality of ideas generated and the actions to resolve issues that arise (d) Cooperation, willingness to cooperate with other people or fellow members of the organization (e) Initiative, a passion for carry out new tasks and responsibilities in enlarging (f) personal qualities, concerning personality, leadership, hospitality and personal intergrita. Thus the performance of employees determine the success of an organization. The strength of any organization lies in its people, so that the achievement of an organization can not be separated from the performance of each individual involved in it. Performance is the attainment of organizational goals that can be quantitative or qualitative form of output, flexibility, and dependability or things desired by the organization. Suppression performance can be short term or long term, can also be at the level of individuals, groups or organizations . performance can also be interpreted as the fulfillment of a duty. An important point is that the performance should be considered broadly. Therefore, the performance of which only focused on the quantity of output will be very unfortunate because it is not based on the quality achieved and the quality should be reached on the terms of the results it can be shown that the quantity and quality of work.

The performance of individual employees who are given on the performance of group work which further contributes to the achievement of organizational performance is crucial work in an organization . Some understanding of the following will enrich our knowledge about the performance, namely: (1) the performance of a set of results and refers to the act of achievement and execution of any work requested (2) performance is one of a total collection of work that is in labor (3) performance is influenced by the purpose, (4) the performance is a function of motivation and ability. To complete a task or job, one must have a degree of willingness and a certain level of ability. Willingness and skill is not effective enough to do something without a clear understanding of what to do and how to do it (5) refers to the attainment of performance goals or tasks assigned employees (6) performance refers to the level of success in performing the tasks and the ability to achieve its intended purpose. Otherwise good performance and success if the desired goals can be achieved with either. Achievement of the set objectives is one measure of individual performance. There are three criteria in assessing individual performance, which is suggested by experts that is: (a) the individual task (b) the behavior of individuals and (c) individual characteristics such as : performance as the quality and quantity of the achievement of the tasks, whether committed by individuals, groups and organizations, the performance as a function of the interaction between the ability or abilities (A), motivation or motivation (M) and the chance or opportunity $(\mathrm{O})$, ie performance $=\mathrm{f}(\mathrm{A} \times \mathrm{M} \times \mathrm{O})$. Meaning : the performance is a function of ability, motivation and opportunity. Thus, the performance is determined by factors of motivation, ability and opportunity. Chance performance is the high performance levels are partly a function of the actions that have been completed and the work that has been through the barriers that hinder employee jobs in high grade.

Thus, the performance is the willingness of a person or group of people to perform an activity and who have perfected the work in accordance with the responsibilities given to the expected results. Performance in carrying out its functions are not stand alone, but associated with job satisfaction and rate of return obtained employment as measured by the performance of the resulting employee. It is influenced by the skills, abilities and traits that many individuals in formal education and acquired through education and training in the duties of office . Therefore, according to the Model-Lawyer Partner said, individual performance is basically influenced by (a) expectations regarding the benefits, (b) encouragement, (c) the ability, needs and characteristics, (d) perceptions of the task, (e) remuneration internal and external, (f) the perception of the level of remuneration and job satisfaction. Thus, the performance is essentially determined by three things: (1) the ability of workers, (2) the desire to work, (3) the work environment. In order to have good performance one must have the ability and desire to do a job of high and know the job is assigned. Own a desire to carry out the work and have a 
comfortable environment to carry out work. Without these three factors, the performance will not be good employees and the expectations of the organization in the achievement of the task will not be achieved. From that perspective, kienrja has four aspects: (1) ability, ( 2 ) receipts organizational tasks clearly and safe working environment and facilities as well as employee benefits in accordance with the employee 's performance is achieved, and (3) have high levels of goal based job standard set up on target them, (4) have a good interaction between the objectives and the ability of workers in the organization. Each of these elements affect the performance of a person or employee to do the job. Therefore, in order to improve employee performance, then the knowledge and skills of performing the task needs to be fostered through education and training is essential to the work carried out so that the task can be carried out with appropriate personnel and well so that organizational goals can be achieved.

For it is the goal of this study was to determine the effect on the performance of education and training of personnel in the district office Sonder Minahasa.

\section{Research Methods}

Penerlitian method used is quantitative penelituan regression and correlation analysis, the research is intended to determine whether there is a relationship between education and training independent variable $(\mathrm{X})$, the dependent variable is the performance of an employee $(\mathrm{Y})$. The analysis technique used is a simple regression analysis techniques and product moment correlation to the amount of variable relationships. The sampling technique using purposive sampling technique.

\section{Results}

District Office Sonder Minahasa district which has a population with a per capita income of the farm. Residents who work in the district offices are expected to have the revenue to support their lives and their work strongly supports the potential for service to the community . Implementation of tasks set by the government district in the government employment regulations contained in the competency -based employee penatan guidelines in urban districts and sub-districts. Based on local regulations on the implementation of tasks Minahasa district staffing arrangements have been made clear in their duties and authority of local government, especially local government districts . Decentralized execution of tasks in the field of employment which includes the implementation and control of field service personnel and services to the public in accordance with the legislation and policies that apply based on the needs of the area with the District Chief assigned task

The results obtained by regression analysis obtained $\mathrm{a}=33.98$ and $\mathrm{b}=0.39$ so the regression equation is : $\mathrm{Y}^{\prime}=33.08+0.39 \mathrm{X}$ that describes the causal relationship between the management of human resources through education and training to performance employees. Where every existence implementation of education and training for district office personnel will increase the quality of work as employee performance achieved in supporting the activities of the district office organization. With the education and training that can improve employee job stability and to improve the way work is less effective, where a lot of work before they are trained tertundah, job tertundah stacked and can overload the employee. The work could not be completed because the employee is not yet clear how the completion of work and education and training after clearance can then work can be completed. Dikerjakankan many employees work less well or not within their assigned. The work less well as the completion of official letters, sometimes do not understand the concept of a given worker / employee that their work is not good. And administration tasks much less understood by the employees so that the need for training is based on the rules of drafting official letters / mail service. And there are many more that need to be fostered in the education and training to be able to be a good job reflecting the performance of employees. Also determine the timeliness of the work. If employees are trained completing the work on time the required discipline in the use of working hours. With discipline when the employee can work efficiently so that more time is not wasted but can finish the job at the time determined and assigned appropriate. With the education and training to encourage employees to develop themselves in their own potential possessed . Employees are trained to develop their existing talent in all forms of their skills and expertise in the field . With adnya education and training of personnel districts increased employee performance and they were satisfied with the work that is accomplished, and the provision of appropriate tasks are clearly assigned to them based on their areas of expertise in education and keahlianya . Assignment given to the employee in accordance districts expertise and his experience. Employees districts equipped with personal gear as office inventory in carrying out official duties to complete the implementation of pekeraanya . The sub-district employees get a sufficient number of hours to finish the job so that the workers and the work can be completed on time and employees feel comfortable and satisfied from their kerjaa results, the results of their work to be good. Given the value of the work that affects the rewards can motivate employees work in the sub-district employees carrying out the work and they can work well and quality. In education and training are taught how to carry out the work with a comfortable and quality so that workers are satisfied with their work. For that employee benefits have been granted based on the results of their work and gain appropriate rewards or work performance, employees who 
work be satisfied. Districts in the job satisfaction of employees creates a feeling of safety in working with dikecamatan group, have a harmonious relationship with the boss, getting within their salary received by the employee benefits job satisfaction, can develop employee performance and provide the widest possible opportunity to develop existing potential through education and training, and can be realized in the work with improved performance. With the education and training of the employees of districts to benefit the organization task districts and sub-district officials in implementing employment can be assigned custom work where work becomes stable. With the education and pelatuhan officials changed the way districts can work quite right, can rapidly develop their potential, work more efficiently, an employee is able to perform the task better , and subdistrict employees are given the opportunity to develop self- regulation at large in the corridor assigned . Employees districts can improve their morale and their work become productive. Employees districts can increase the spirit of devotion, have extensive knowledge to carry out the task , can develop the knowledge , skills and expertise . Employees districts can develop positive thinking patterns, rational and objective and can create or develop a better working methods and to build a career as an employee of a potentially districts. Thus all the work that is assigned to the sub-district employees in all areas of work can be done well by all employees of districts

This relationship is obtained after the analysis of the correlation relationship obtained : for the variables $\mathrm{X}$ and $Y$ then $r=0.54$. Figures correlation coefficient of $r=0.54$. can give the interpretation of the strength of the relationship variables, then use the following guidelines :

Tabel 1. Provide guidelines for the interpretation of the correlation coefficient

\begin{tabular}{|l|l|}
\hline Interval Coefficient & Level Relations \\
\hline $0,00-0,199$ & very low \\
$0,20-0,399$ & low \\
$0,40-0,599$ & moderate \\
$0,60-0,799$ & strong \\
$0,80-1,000$ & very Strong \\
\hline
\end{tabular}

Based on the above table, the correlation coefficient was found to be 0.54 which means that there is a relationship being between human resource management through education and training with employee performance where other relationships influenced by other factors not examined. The coefficient determinant for the contribution of variable $\mathrm{X}$ to $\mathrm{Y}$ can be viewed by using the coefficient determinant by squaring the correlation coefficient $(\mathrm{r}), \mathrm{r} 2=0.29$ was found. Figures determinant coefficient of 0.29 indicates that the influence of education and training for employees kecamata office workers on their performance by $29 \%$ while $71 \%$ influence on the performance of other employees due to other factors beyond education and training. Thus the significance test shows, $\mathrm{H} 0=$ There is no influence of the management of human resources through education and training on employee performance at the District Office Sonder and $\mathrm{Ha}=$ There is the influence of the management of human resources through education and training on employee performance at the District Office Sonder Minahasa. Or hypothesis Ha is accepted . In t table $=2.052$ means that there is an influence on the management of human resources through education and training on employee performance at the District Office Sonder Minahasa. This proves that there are significant human resource management through education and training on employee performance at the District Office Sonder according to a simple linear regression analysis techniques, product moment correlation, coefficient of determination and significance test. Where if dilasanakan education and training for employees of the districts will increase employee performance. Need him adnya human resource management efficiently through education and training for district office personnel. With the education and training of the employees of the districts will have knowledge about their workload as the workload with the number of the target job or target outcomes to be achieved within a certain time unit of every employee districts. Employees may know the standard average ability ( SKR ) owned employee or achievement standards that the average employee will be achieved is a standard capability that shows the size of the average energy provided by a sub-district employee to do the job. Measuring results can be measured melelui employee work unit count indicated as work performance . Results ditujunjukkan work through the calculation workload achieved is a technique to set a time for an employee who meets the requirements of ( qualified ) to complete a particular job with predetermined performance standards. It can menunjuukan district office employee performance generated . Performance SDO staff employees must conform formation and composition of the rank is the number of employees employed in the organizational unit to be able to perform basic tasks and functions within a specified period according to the functions and duties given rank in staffing positions or functions assigned tasks subdistrict head. In the education and training of personnel districts have been provided with role assignment to be done in accordance with jabatanya or position which shows their duties and responsibilities, authority, they and the right of a civil servant in an organizational unit kecamtan given to the government district . Education and training at the district office officials also been equipped with the function of the office duties involving structural position that indicates the position duties, responsibilities, authority and 
rights of a person in order to lead Servants hand and carry out the work assigned to the organizational unit of the district office. Thus, the performance of employees in the districts can be increased and that greatly affect the performance of the employees working with the district office provisioning functions such tasks. The subdistrict employees in education and training that produces good performance in the organization due to the district office by office tasks fngsional provisioning functions. That is a position that indicates the task to be done, authority in the work, and the person's right of civil servants to perform a unit of work organization and execution of work tasks based on a particular skill or skills that are independently owned and the employees for promotion and promotion requirements in carrying out the task on their level and it is possible to develop a task at a higher level in accordance with the required number of credits in the amount of the resulting performance of the work, employees also can perform certain tasks properly. In the education and training of district office personnel are also equipped with general knowledge about the functional position that indicates a position in function of the duties, responsibilities, authority and public servants the right person in an organization unit districts in the execution of their duties which are based on certain skills and for his promotion are not number of credits required to support subsequent career but that can be demonstrated through the performance of work achieved sub-district employees. Thus through education and training sub-district employees can improve their work performance. Standard capabilities districts after workers through education and training can be measured in units of time called the norm of working time. Norma time is one time unit used to measure how the results can be obtained from the notation or calculation of the norm of working time multiplied by the work . For example, a typist within 30 minutes to produce 2 sheets of typing . Then the normal time is multiplied by one person working time typist 30 minutes, producing 2 sheets of typing so average strander ability of a typist is 30 minutes to produce 2 sheets of typing. With the education and training that each employee can memperhitingkan the results of their work performance menunjuukan kenerja timely work . Management of human resources through education and training strongly affect the results of the employee 's workers' district office Sonder. This can be demonstrated by the performance and the performance of the work produced. Through education and training of the leadership SDO can also menentukkan assessment of their work in a predetermined standard value. It is expected the participation of active participation in the implementation of education and training for district office personnel, resulting in improved quality of district office employee . Because of the results of the study suggest a link between the education and training of human resources with the district office employees work performance of employees, the district office Sonder Minahasa district seen from the work / employee performance

\section{Conclusions And Suggestions}

There is the influence of human resource management through education and training to the improved performance of employees in the District Office Sonder Minahasa District, thus supporting the implementation of the services provided to employees of the sub-district head. And as a suggestion, is expected to sub-district government agencies need to improve the management of human resources through the implementation of educational programs and training positions, so that performance can be increased to a maximum of employees in carrying out their work or their work to be optimal. Therefore employees who have attended the training, attitudes and behavior they show better, more obedient in carrying out the work, the better the results of their work, can be an example to other employees who have not been trained. Staff employees to be disciplined and obedient in following the prescribed rules. Employees can perform well all assigned work and can overcome any problems faced. Education and training is urgently needed to improve the productivity and quality of work of employees to achieve organizational goals ang targeted at the district office. Chief districts namely Mr. camat in this case is a key element in efforts to influence the employee in performing the work, contribute their expertise, either to act on that ability yan owned and ability to grow and evolve constantly. Employees can carry out the tasks assigned in accordance with the policies made in the work program that has been direncanakanm and is set to be implemented. With the education and training of employees can be motivated, employees have a strong commitment to improve its performance in the achievement of organizational goals and the district office for the district of Minahasa progress in general

\section{References}

[1]. Mangkunagara, Anwar P. 2005, Human Resource Management, London: Notoatmodjo, Soekidjo. , 2003. Human Resource Development. Jakarta:Rineka Copyright

[2]. - -------., 2009. Human Resource Development. Jakarta: Rineka Reserved Riani L. Asri. , 2010. Organizational Culture. London: Graha Science Sedarmayanti. , 2007. Human Resource Management. Bureaucratic Reform and Management of Civil Servants.

[3]. London: Refika Aditama Sugiyono. , 2003. Administrasi.Bandung Methods: CV.Alfabeta Saliman. Employee Development through Education and Training.

[4]. http://staff.uny.ac.id/system/files/penelitian/Saliman,\% 20Drs.\% 20M.Pd./Pengembangan\% 20Pegawai.pdf

[5]. Law No. 8 of 1974 on the main points of staffing Act No. 43 of 1999, Article 1, paragraph 1: on Civil Servants Government Regulation No. 97 Year 2000 on the Formation of Civil Servants Government Regulation No. 54 of 2003; 